\title{
エネルギ一消費統計調査の 弯蜜
}

\section{笠原 誠}

資源エネルギー庁では, 平成 19 年度エネルギー消費統計調査 をして実施した。 エネルギー消費統計調査は，製造業の一部を 対象とした石油等消費動態統計等以外で, 今まで未整備な分野 についてのエネルギー消費実態を把握するために実施してい る. また, 地球温暖化の原因といわれる温室効果ガスは, エネ ルギー消費起源が大勢を占めていることから, エネルギー問題 のみならす環境問題への施策をうつためにも，業種別のエネル ギー消費実態の把握は重要となっている。本稿では, エネルギ 一消費統計調查の概要, 調查実施上の問題点, 調査結果の利用 方法等について述べる.

\section{1.はじめに}

資源エネルギー庁では，平成 20 年度に，平 成 19 年度エネルギー消費統計調査を統計報告 調整法に基づく報告徵集（承認統計調査）とし て実施した。

エネルギー消費統計調査は, 中国をはじめと するアジア諸国の経済成長に伴うエネルギー石 油需要の増大と主要産油国での供給不安に伴う 原油高騰からエネルギー消費実態の把握につい て精緻化を求められているため実施している.
また, 地球温暖化の原因といわれる温室効果ガ スは，エネルギー消費起源が大勢を占めてお り, エネルギー問題のみならず環境問題への施 策をうつためにも，業種別のエネルギー消費実 態の把握は重要となっている。

本稿では，エネルギー消費統計調査の概要， 調查実施上の問題点，調查結果の利用方法等に ついて述べることにする。

笠原 誠 資源エネルギー庁総合政策課エネルギー政策企画室 †100-8931 東京都千代田区霞カ関 1 丁目 3 番地 1 号 


\section{2. エネルギー消費統計調查の必 要性}

中国を初めとするアジア諸国のエネルギー需 要の増大により, 今後エネルギー需給が国際的 に逼迫することが予想される中で, IEA（国際 エネルギー機関) 等の国際機関からは, 各国に おいてエネルギー需給実態をより精緻に定量的 に把握することが求められている.

特に, 地球温暖化問題については, 我が国で は平成 14 年 6 月に京都議定書を国会承認し, 温室効果ガスの削減目標（90 年度比 $\Delta 6 \%$ ) を達成することを国際的に約束している。その 具体的取組みとして, 平成 17 年 4 月に閣議決 定された「京都議定書目標達成計画」において は，「部門別の排出実態をより正確に把握する とともに, 各主体による対策の実施状況の評価 手法を精査するため, 活動量として用いる統計 の整備」を行うことが定められた. 温室効果ガ スのうち, 二酸化炭素 $\left(\mathrm{CO}_{2}\right)$ については, そ の約 9 割がエネルギー起源であり, 国民の経済 社会活動全般にわたるエネルギー消費実態をよ り精緻に把握することが必要となっている.

他方, 現在の我が国のエネルギー分野の統計 についてはいくつかの課題が指摘されており, 我が国における国及び地方自治体レベルでのエ ネルギーの適正な利用の推進, 地球温暖化問題 への対応など，現下の諸情勢をふまえたエネル ギー・環境政策の企画・立案を図るためには, エネルギー消費の地域別, 業種別等に把握し, エネルギー消費構造を精緻に分析できるような 統計を早急に整備する必要がある.

\section{3 、エネルギ一消費統計調查の概 要}

\section{3-1 調査の目的}

我が国の産業部門・業務部門におけるエネル ギー消費実態の産業別・都道府県別の把握を目
的とした統計を整備するため, 調査対象の範 囲, 調査の実施方法, 調査票様式等の具体的内 容を再設計し, 次回調查の設計に必要な各種情 報を得るために平成 19 年度エネルギー消費統 計調查を実施した。

\section{3-2 調査の範囲と方法}

調査の範囲は，以下の通りである.

(1)「経済産業省特定業種石油等消費統計調 查(指定統計第 115 号)」の「石油等消費動 態統計」の全対象事業所は重複排除する.

(2)「エネルギーの使用の合理化に関する法 律（以下，省工ネ法）定期報告書提出対象 事業所（第 1 種・第 2 種エネルギー管理指

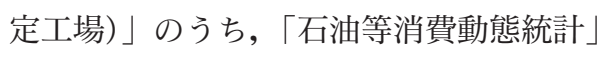
の対象事業所を除いた事業所を調査の対象 とする.

(3) (1), (2)以外の事業所については, 平成 18 年事業所・企業統計調査を母集団名簿 とし, 調査対象となる事業所を選定する。 ただし，以下の業種については，エネルギ 一消費量を調査する調査の対象外とする.

- 農業 (日本標準産業分類: 大分類 A) のうち, 耕種農業（日本標準産業分類： 小分類 011）及び畜産農業（日本標準産 業分類：小分類 012）（農業経営統計調 查の調査対象のため)

- 電気業（日本標準産業分類：中分類 33) のうち「電気事業法による一般電気事業 者, 卸電気事業者, 特定電気事業者, 特 定規模電気事業者」の発電所 (電気事業 法による報告範囲),

・ガス業（日本標準産業分類：中分類 34) のうちガス製造工場（ガス生産動態統計 の調査対象),

- 鉄道業（日本標準産業分類：中分類 42) の本社等以外（鉄道事業法の報告範囲 外),

- 貸家業・貸間業（日本標準産業分類：小 分類 692), 駐車場業 (日本標準産業分 類：小分類 693）のうち, 個人経営の事 
業所（居住部分がほとんどあるいは分離 が困難な事業所),

・その他の宿泊業のうち他に分類されない 宿泊業（日本標準産業分類：小分類 7299 (事業所・企業統計調査産業分類： 72 B)）（多くは寄宿舎や社員寮などなの で居住部分とみなした)。

(4) 電気業（日本標準産業分類: 中分類 33), ガス業（日本標準産業分類：中分類 34）については，「電気事業法による一般 電気事業者，特定電気事業者，特定規模電 気事業者」,「ガス事業法による一般ガス事 業者，ガス導管事業者による大口供給許 可・届出事業者，大口ガス事業者による大 口供給許可・届出事業者」に対して, 需要 家側からのデータとの整合性を検証するた めに，総供給量及び産業別・都道府県別供 給量を調査する。

調查の方法は以下の通りである.

(1) 調査票を含めた調査の企画設計に関して は資源エネルギー庁にて実施した。

(2) 調查票の配布 (郵送), 督促, 回収, 審 査（サマリー審査を除く），集計等の事務 に関しては民間調査機関にて実施した。

(3) 調査結果の分析については資源エネルギ 一庁にて実施する。

\section{3-3 調査事項と調査票の種類}

調査は, 平成 20 年 3 月末日とした平成 19 年 度の実績でまとめられている。

調査事項と調査項目は(1)〜 (5)のようになって いる.

(1) 事業所の名称，所在地

(2) 企業の名称, 所在地

(3) エネルギー源別消費量又は消費金額（年 度計)

(4) エネルギー消費量と密接な関係を持つ 「活動量」

（従業者数, 延床面積, 売上高（公務を 除く))

(5) 電気業及びガス業の産業別・都道府県別
販売量

調査票の種類と対象数は以下の通りである. 調查票第 1 号 148,652 第 2 号，第 3 号以 外

調查票第 2 号 9,465 林業, 漁業, 鉱業, 建設業

調查票第 3 号 16,414 国，地方自治体等 調查票第 4 号 2,048 平成 18 年度調査の ビル等全体把握者

調查票第 5 号 2,863 省エネ法定期報告 対象事業所（ビル等）

調查票第 6 号 $\quad 8,013$ 省エネ法定期報告 対象事業所 (ビル等以外)

調查票第 7 号 183 熱供給事業者，熱 供給業

調查票第 8 号 30 電気事業者

調查票第 9 号 237 ガス事業者

\section{4. エネルギー消費統計調査が抱 える課題}

エネルギー消費統計には，次の 4 つの課題を 抱えている。

（1） 省エネ法定期報告との関係を整理し，定 期報告の内容がエネルギー消費統計に利用 可能かを検証すること.

(2) 試験調査と予備調查において調査対象外 とした農業について，既存の統計資料から 推計可能かの検証すること。

（3）工事現場など屋外における燃料消費の調 查手法を検討し，省エネ法の定期報告にお いても建設業などの屋外の燃料については 報告対象外となっているので，エネルギー 消費統計においてどのように補足するかを 検討すること。

(4) 多くの事務所系ビルや大規模なショッピ ングセンターにおけるエネルギー消費の実 態について，調査を実施しても，回答困難 なテナントの消費量をどのようにして補足 するかを検討すること。

以下は，平成 18 年度予備調査（平成 19 年度 
表 1 省エネ法の工場・事業場に係る措置

\begin{tabular}{|c|c|c|}
\hline & 基準 & 義務 \\
\hline $\begin{array}{l}\text { 第一種エネルギー } \\
\text { 管理指定工場 }\end{array}$ & $\begin{array}{l}\text { エネルギー使用量 } \\
\text { (原油換算) } \\
3,000 \mathrm{kl} / \text { 年以上 }\end{array}$ & $\begin{array}{l}\text { ・エネルギー管理者の選任義務（事業場は管理 } \\
\text { 員で可) } \\
\text { ・ 中長期計画の提出義務 } \\
\text { ・ エネルギー使用状況等の定期報告 } \\
\text { 世判断基準に照らし著しく不十分であるとき大 } \\
\text { 臣の指示, 公表, 命令 (罰則) }\end{array}$ \\
\hline $\begin{array}{l}\text { 第二種エネルギー } \\
\text { 管理指定工場 }\end{array}$ & $\begin{array}{l}\text { エネルギー使用量 } \\
\text { (原油換算) } \\
1,500 \mathrm{kl} / \text { 年以上 }\end{array}$ & $\begin{array}{l}\text { ・エネルギー管理員の選任義務 } \\
\text { ・エネルギー使用状況等の定期報告 } \\
\text { 世判断基準に照らし, 著しく不十分であると } \\
\text { き, 大臣の勧告 }\end{array}$ \\
\hline
\end{tabular}

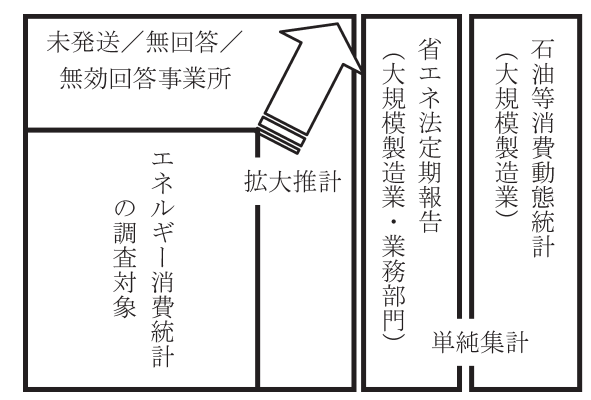

図 1 省エネ法定期報告データの利用イメージ

実施）においてその検証結果について整理した ものである。

\section{（1）エネルギーの使用の合理化に関する法律} （省エネ法）に基づく定期報告との関係整理

(1) 他の調査との相違

エネルギー消費統計は,「石油等消費動態統 計」がカバーしていない中小製造業や 9 業種以 外の製造業，業務部門のエネルギー消費量を把 握するために開始したものである. エネルギー 消費統計の調査項目は石油等消費動態統計の調 查項目に準拠している.

このため, エネルギー消費統計では石油等消 費動態統計対象事業所は直接調査対象とはせ ず，エネルギー消費統計の集計結果に石油等消 費動態統計の結果を足し合わせることにより， 全国のエネルギー消費量を推計することとして いた。

一方，「エネルギーの使用の合理化に関する 法律」(省エネ法)における, 工場・事業場 （ビル等含む）に対するエネルギー消費量の定 期報告制度では, 工場・事業場のエネルギー消 費量や原単位の経年比較を行い, 省エネルギー
を促すことを目的としてエネルギー消費量を報 告させている。その概要は次の通りである.

図 1 のように, 省エネ法定期報告の報告内容 をエネルギー消費統計に利用することができれ ば，省エネ法定期報告の対象者に対しても，石 油等消費動態統計対象事業所と同様, エネルギ 一消費統計の対象外とすることが可能である.

(2) 平成 18 年度予備調查における省エネ法 定期報告との検証の実施

平成 18 年度予備調查においては, エネルギ 一消費統計とのデー夕整合性を確認するため に, 省工六法定期報告対象事業所（石油等消費 動態統計対象事業所を除く）に対しても調査を 実施した。

特に，全ての業務部門の事業所 ${ }^{1)} に$ 対して は, 自ら使用したエネルギー消費量に加えて, 共用部，テナント部のエネルギー消費量につい て,「第 4 号調查票」によって調査を実施した。 その他の事業所に対しては, 自ら使用したエネ ルギー消費量を調查する「第 1 ～ 3 号調査票」 を送付した。省エネ法定期報告によるエネルギ 一消費量が利用可能であれば，記入者負担の軽 


\section{表 2 エネルギー消費統計・省エネ法定期報告}

【エネルギー消費統計（H 18 年度予備調查） 4 号】

C 1. 延床面積

C 2. 電力消費量

C 3, B 1. 燃料消費量

燃料種別

用途別

C 4, B 2. 熱 (蒸気・温水・冷水)

(発生

消費

販売

C 5,B 3. 自家発電

発電量

販売・提供量

C 6. 回答の範囲
【省工ネ法定期報告 (H 17 年度)】

第 1 表 エネルギーの使用量及び販売副生エネ ルギー等の量

- 燃料種別

・仕向別（自ら使用，販売，生産寄与 分以外)

第 2 表 （省略）

第 3 表 生産数量等

(エネルギー使用量と密接な関わりが ある指標)

第 4 表 エネルギーの使用に係る原単位

第 5 表 同（過去 5 年度の変化状況）

第 6 表 原単位改善できなかった理由等

第 7 表 （省略）

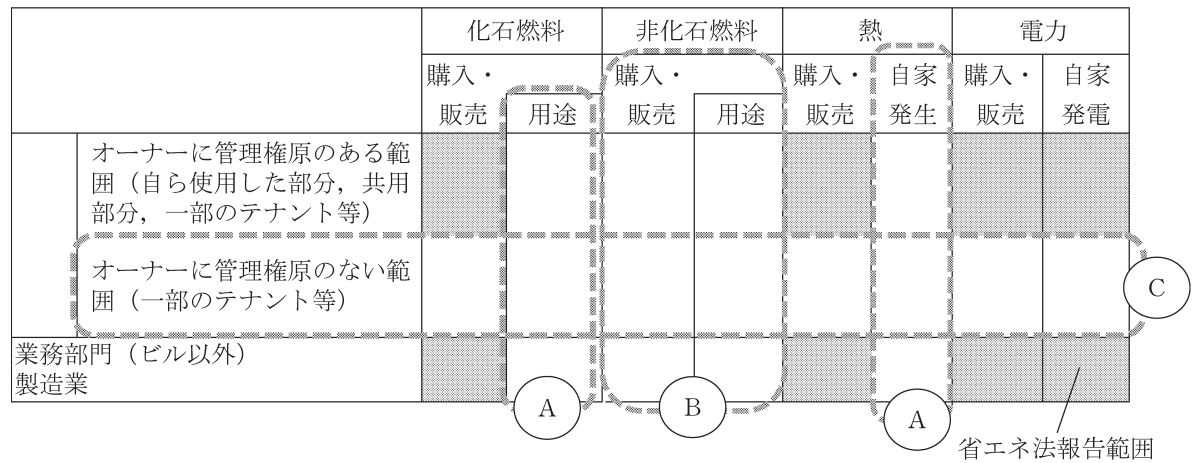

※：エネルギー消費統計の報告範囲は，この全体である。

図 2 エネルギ一消費統計に比較した省エネ法の報告範囲

減を図ることが可能になる.

そのために，省エネ法定期報告の内容を整理

してエネルギー消費統計・石油等消費動態統計 の調查項目と比較するとともに，定期報告にお けるエネルギー消費量とエネルギー消費統計が 調査したエネルギー消費量についての比較を行 った.

エネルギー消費統計及び石油等消費動態統計 における調查項目と省エネ法定期報告の報告内 容は完全には一致しないため，省エネ法定期報 告の活用には以下の課題があると考えられる。

これらの課題の解決のためには, エネルギー 消費統計の実施段階・集計段階で対応すべきも の, 省エネ法定期報告の実施段階・集計段階で 対応可能なものの両面から検討してみた。

エネルギー消費統計・石油等消費動態統計と 省エネ法定期報告には, 図 2 に示すような報告 範囲の差がある。これは, 以下の(A)〜Cにまと
めている.

(A) 燃料の用途別調査がない.

定期報告では，燃料の用途の報告を求めてい ないため，事業所内におけるエネルギー転換 （蒸気発生，自家発電，コージェネ等）を表現 することができない。エネルギー消費統計の集 計においては，一定量をエネルギー転換に用い ているものと見なして推計し，省エネ法定期報 告の実施段階における対応案として，自家発電 にかかる効率等のデー夕を報告項目に加える， （自家発電量は報告対象であるため，エネルギ 一転換用燃料消費量の逆算は可能であるが，燃 料を特定することはできない.）などの対策が 必要となる。

(B) 非化石燃料消費の報告がない。

廃夕イヤ，廃材等の非化石燃料が報告の対象 外となっている他，非化石燃料のみから発生し た電気や熱についても報告の対象外となってい 
るため，エネルギー消費の範囲が限定されてし まう（例えば，ある事業者が水力による自家発 電を行い，その電力を消費している場合には， 電力消費はゼロになる)。このため, エネルギ 一消費統計の集計段階における対応案として は，過去デー夕等によるトレンドや，石油等消 費動態統計の結果等から，一定量の非化石燃料 を使用していると仮定して推計を行う, 省エネ 法定期報告の実施段階における対応案として は，定期報告でデー夕を追加するなどの対策が 必要である。

\section{C) 報告範囲の違い}

省エネ法定期報告では, エネルギー管理者が エネルギー管理権原のある範囲でのエネルギー 消費量を回答することとなっている. 一方で, エネルギー消費統計では，ビル全体（業務部門 の一部), もしくは事業所単位のエネルギー消 費量を調査しているため, 回答量には乘離が生 じる.

ビル・ショッピングセンター等のエネルギー 管理権原やエネルギー把握については次の内容 が指摘されている.

・電力 : ビルオーナーが一元管理しているこ とが多く，省エネ法においてもビル全体の 消費量が記載されていることが多い.

・都市ガス・LPG 等 : 各テナントが個別契 約していることが多く, 省エネ法における

報告対象外となっていることが多い.

以上のことからエネルギー消費統計の集計段 階における対応策としては, 省エネ法定期報告 範囲に対応する事業所範囲を, 名簿デー夕の名 寄せにより特定し, ビル内の報告されていない 部分のエネルギー消費量を補完する（業務部 門)。もしくは, 各事業所単位のエネルギー消 費量に按分する。

省エネ法利用の実務上の課題として，前述 の他, 省エネ法定期報告の利用には次のような 課題がある。

・集計時期の違い

定期報告の提出期限はデー夕対象年度の次年 度 6 月末日（デー夕集約には更に数ヶ月必要）
であり，エネルギー消費統計の集計，公表時期 には間に合わないので，エネルギー消費統計の 集計・公表夕イミングを調整や, 定期報告の集 計時期の早期を依頼することなどが考えられ る。

- 対象事業所の変化

対象事業所は政策動向によって変化する可能 性があり, 集計結果が不安定になる可能性があ る。エネルギー消費統計の実施段階における対 応案としては, 変更の度に, 調査設計や集計方 法を見直す必要がある。

\section{（2）農業部門におけるエネルギー消費の把握 の手法}

平成 18 年度までのエネルギー消費統計調査 では, 産業大分類 $\mathrm{A}$ 農業を対象外としている が, これは, 農業という特殊性が対象を把握す るのが困難であることに帰依している．このエ ネルギー消費統計調查での母集団である事業 所・企業統計において対象範囲としているの は, 約 2 万事業所の法人格を有する農業であ る. 一方, 農林業センサスでは約 200 万の農業 事業所 (農家) が存在する。本稿では, 実査に よる農業のエネルギー消費の把握でなく, 既存 の統計調查からエネルギー源別消費金額と金額 から数量への換算の推計を行った。

(1) エネルギー源別消費金額の推計

農業経営統計調査では, 個別経営, 組織法人 経営について農家・経営体あたりの光熱動力費 の集計結果が掲載されている。任意組織経営に ついては, 経営形態別経営統計が存在しないた め, 便宜上営農類型別経営統計の「水田作経 営」の光熱動力費を用いる.

当該光熱動力費に, 農業物価統計における光 熱動力費の品目別ウエイト（ガソリン，灯油 等）を乗じることにより，品目毎の消費金額を 推計する。（現時点においては平成 12 年基準の ウエイトが最新值であるため, これを採用す る.)

(2) 金額から数量への換算推計

金額で算出したエネルギー源を数量に変換す るために以下の処理を行う。 
表 3 農事用電力（潅溉排水用）単価

\begin{tabular}{|c|c|c|c|c|}
\hline & 基本料金 & \multicolumn{2}{|c|}{ 従量料金（円/kWh） } & \multirow{2}{*}{$\begin{array}{c}\text { 農事用電力 } \\
(\mathrm{MWh})\end{array}$} \\
\hline & (円/kW・月) & 夏期 & その他 & \\
\hline 北海道電力 & 693 & \multicolumn{2}{|c|}{7.86} & 24,291 \\
\hline 東北電力 & 598.5 & 7.64 & 6.95 & 146,933 \\
\hline 東京電力 & 420 & 7.72 & 7.02 & 316,276 \\
\hline 中部電力 & 525 & 6.63 & 6.05 & 74,107 \\
\hline 北陸電力 & 493.5 & 5.72 & 5.2 & 30,966 \\
\hline 関西電力 & 598.5 & 7.22 & 6.55 & 59,480 \\
\hline 中国電力 & 735 & 8.78 & 7.98 & 27,910 \\
\hline 四国電力 & 714 & 8.76 & 7.96 & 30,477 \\
\hline 九州電力 & 610 & 8.95 & 8.14 & 142,899 \\
\hline 沖縄電力 & 850.5 & 10.33 & 10.28 & 7,745 \\
\hline 加重平均 & & \multicolumn{2}{|c|}{7.5} & \\
\hline
\end{tabular}

\begin{tabular}{|c|c|c|c|c|c|}
\hline & (a) & (b) & (c) & (d) & (e) \\
\hline 個別経営 & $\begin{array}{c}\text { 光熱動力費 } \\
\text { (千円/戸・年) }\end{array}$ & ウェイト & $\begin{array}{l}\text { 費目別消費額 } \\
(千 円 / 戸 ・ \text { 年) }\end{array}$ & 単仾 & $\begin{array}{c}\text { 費目別消費量 } \\
(\mathrm{L}, \mathrm{kWh} / \text { 戸 年) }\end{array}$ \\
\hline 組織法人経営 & $\begin{array}{c}\text { 光熱動力費 } \\
\text { (千円/経営体・年) }\end{array}$ & $\begin{array}{l}\cdot \text { •ガソリン } \\
\text { ・灯油 } \\
\cdot \text { 軽油 } \\
\cdot \text { 重油 }\end{array}$ & $\begin{array}{c}\text { 費目別消費額 } \\
(千 \text { 経営体・年) }\end{array}$ & $\begin{array}{l}\cdot \text { •ガソリン } \\
\cdot \text { 灯油 } \\
\cdot \text { 軽油 } \\
\text { ·重油 }\end{array}$ & $\left\{\begin{array}{c}\text { 費目別消費量 } \\
(\mathrm{L}, \mathrm{kWh} / \text { 経営体・年) }\end{array}\right.$ \\
\hline 任意組織経営 & $\begin{array}{c}\text { 光熱動力費 } \\
(千 \text { (千経営体·年) }\end{array}$ & $\begin{array}{l}\text { ·農用電力 } \\
\text { ·水道料 }\end{array}$ & $\begin{array}{c}\text { 費目別消費額 } \\
\text { (千円/経営体・年) }\end{array}$ & $\begin{array}{l}\text { ·農用電力 } \\
\cdot \text { 水道料 }\end{array}$ & $\begin{array}{c}\text { 費目別消費量 } \\
(\mathrm{L}, \mathrm{kWh} / \text { 経営体・年) }\end{array}$ \\
\hline
\end{tabular}

$(\mathrm{c})=(\mathrm{a}) *(\mathrm{~b}),(\mathrm{e})=(\mathrm{c}) *(\mathrm{~d})$

図 3 品目（エネルギー源）別消費量の推計イメージ

単価については，毎年の平均值が農業物価統 計において把握されているため, 対象年の単価 を用いてエネルギー量に換算する。なお，農用 電力については $30 \mathrm{kWh} /$ 月単位での単価が掲 載されており，同単価には基本料金と従量料金 が含まれることから，以下の通り推計を行っ た。

一般電気事業者 10 社の農事用電力（潅溉排 水用）の単価を表 3 に示す。なお，東北電力， 中部電力, 北陸電力, 中国電力においては育 苗・栽培用熱源動力, 中国電力, 九州電力にお いては脱穀調整用動力としての農事用電力契約 （別単価）も存在するが，便宜上，潅溉排水用 の単価を用いた推計とする．各社の農事用電力 単価と同供給量より従量料金分の加重平均をと ると， 7.5 円/kWh となる. 農業物価統計の農 用電力は $30 \mathrm{kWh} /$ 月単位での単価であるため,

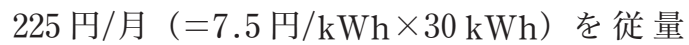
料金分, 残りを基本料金分と想定する. 金額 $\rightarrow$
エネルギー量の換算に際しては，消費金額から 基本料金 $\times 12$ ケ月相当を引いた上で 7.5 円/ $\mathrm{kWh}$ で除した值を，エネルギー量と見なした。 推計に際しては, 個別経営, 組織経営の両デ ー夕が揃う平成 16 年を対象とした。個別経営, 組織法人経営, 任意組織経営の光熱動力費はそ れぞれ 165 千円/戸，6,775千円/経営体，350 千円/経営体である。

上記光熱動力費に農業物価統計のウエイトを 乗じて品目別の消費金額を算出し，全国平均価 格で除して数量に換算する。この值に，総合エ ネルギー統計における発熱量を乗じることによ り, 農家・経営体あたりのエネルギー源別消費 量を推計する。

個別経営農家あたりのエネルギー消費量は約 80 GJ，組織法人経営体あたりのエネルギー消 費量は約 3,300 GJ, 任意組織経営体あたりの エネルギー消費量は約 170 GJ と推計される.

この值に, 組織形態別経営体数の総数を乗じ 
表 4 ビルのエネルギ一消費の分割

\begin{tabular}{l|l|l}
\hline \multicolumn{2}{l|}{} & \multicolumn{1}{|c}{ 調查で想定したエネルギー消費の例 } \\
\hline \multicolumn{2}{l}{ 共用部 } & ・エレベータ, 通路等におけるエネルギー消費. \\
\hline 共用部以外 & オーナー専有部 & $\begin{array}{c}\text { ・オーナーが使用している事務所・店舗等スペースに } \\
\text { おける, 照明や空調, 調理等のエネルギー消費. }\end{array}$ \\
\cline { 2 - 3 } & テナント部分 & $\begin{array}{c}\text { ・テナントが使用している事務所・店舗等スペースに } \\
\text { おける, 照明や空調, 調理等のエネルギー消費. }\end{array}$ \\
\hline
\end{tabular}

て, 日本全体としての農業部門におけるエネル ギー消費量を推計すると, 約 183 PJ となる. これは，日本全体の最終エネルギー消費（約 $16,000 \mathrm{PJ}$ ）の約 $1.1 \%$ に相当する.

\section{(3) 輸送部門を除く屋外におけるエネルギー 消費の把握}

輸送部門については, 自動車輸送統計, 航空 輸送統計, 鉄道輸送統計, 港湾統計等から大凡 の情報が入手可能となるため, このエネルギー 消費統計においては，鉄道を例にとると，鉄道 会社の本社支社など直接事業に付随しない範囲 を対象としている。逆に自動車輸送統計の対象 外となっている救急車, 消防車, パトカーなど の緊急車両, 自動車教習車などが使用する燃料 も対象範囲としている。

しかし, 輸送部門以外に屋外を主として経済 活動を行っている農林水産業, 鉱業, 建設業の 農業機械, 建設機械, 漁船などの消費する燃料 も補足する必要がある。特に，この中で困難を 極めるのが建設現場におけるエネルギー消費量 を補足することである。一般的に工事現場にお いては，元請け（ゼネコン）の下に数多くの下 請け業者が加わり作業を進めている。実際エネ ルギーを消費するのは, 小規模の業者であり対 象の補足も難しく, さらに重機は建設リース会 社がオペレーションを行うことが多く, 複雑に なっている. 予備調査においては，このような 業種を調査票第 2 号として調査を実施したが, 前述の課題が解決してはいなく, 引き続きこの 課題に対する検討をしていく必要がある.

\section{（4）ビル等のエネルギー消費実態の把握}

「平成 17 年エネルギー消費統計（仮称）のた めの試験調查（第二次）」の調査では, 事業所 のエネルギー消費把握状態に関わらず無作為抽
出を行い，エネルギー消費量を調査した。この とき，次のような問題点を見いだした。

・テナントでは自身のエネルギー消費量を把 握していない場合が多かった。

・ビルの共用部（空調，エレベータ等）のエ ネルギー消費を誰が回答するのかについ て，明確な基準がなかった。

・省エネルギーの推進の観点からは, 業種単 位のみではなく建物単位でのエネルギー消 費量の把握が必要である.

そこで，「平成 18 年度エネルギー消費統計調 查 (仮称) 予備調査」では，ビル等の建物（以 下ビルと総称する）について，所有者（オーナ 一), テナントの双方に調査を行い，ビルの工 ネルギー消費量の効率的な把握のための調査を 実施した。

予備調查では, 表 5 に示す方法で, オーナー (第 4 号) やテナント（第 $1 \sim 3$ 号）に調查を実 施した。

大規模ビルの一部を対象としている「省エネ 法定期報告」対象事業所のうち業務部門の事業 所 ${ }^{2)}$ について, 所有者とその建物に入居して いるテナントを調査対象とした。

調査対象は，具体的には以下の通りである.

・オーナー：省エネ法定期報告事業所約 13 , 000 のうち, 事業所名称から, ビル, ショ ッピングセンター, 空港, ホテルと判断さ れた約 2,000 の事業所.

・テナント：上記約 2,000 事業所と同一敷地 にいるテナント総数約 7 万のうち，下記の 計約 5 万の事業所.

一同一敷地内に複数の省エネ法定期報告事 業所がある，もしくはテナントが 50 以 下の場合の，全てのテナント. 
表 5 予備調査におけるビル, テナントの調査方法

\begin{tabular}{|c|c|c|}
\hline & 省エネ法定期報告対象ビル & その他の一般ビル \\
\hline オーナー & $\begin{array}{l}\text { 「第 } 4 \text { 号調查票」を送付し, 把握しているエ } \\
\text { ネルギー消費量を, 自ら使用分, 共用部, テ } \\
\text { ナント部に分けて回答させる. (表 } 4 \text { 参照) }\end{array}$ & $\begin{array}{l}\text { 中分類・規模別に抽出率を定め, 「第 } 1 \text { 号調 } \\
\text { 查票〜第 } 3 \text { 号調查票」を送付する. 建物全体 } \\
\text { のエネルギー消費量を把握していれば, 自ら } \\
\text { 使用分, 共用部, テナント部に分けて回答さ } \\
\text { せる. }\end{array}$ \\
\hline テナント & $\begin{array}{l}\text { 「事業所・企業統計」上で, オーナーの住所 } \\
\text { とのマッチングを行い, テナントを特定す } \\
\text { る.「第 } 1 \text { 号調査票〜第 } 3 \text { 号調査票」を送付 } \\
\text { し, エネルギー消費量を把握できる範囲で回 } \\
\text { 答させる. }\end{array}$ & $\begin{array}{l}\text { 中分類・規模別に抽出率を定め,「第 } 1 \text { 号調 } \\
\text { 査票〜第 } 3 \text { 号調査票」を送付する. エネルギ } \\
\text { 一消費量を把握できる範囲で回答させる. }\end{array}$ \\
\hline
\end{tabular}

オーナーへの調査

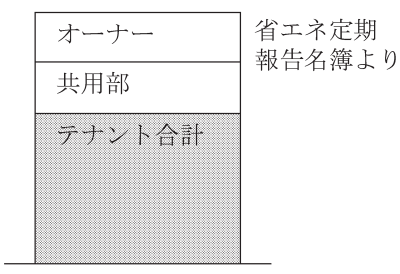

調查項目

·延床面積

・エネルギー消費量

\section{各テナントへの調査}

事業所・企業統計上で 同じ敷地に存在する事業所

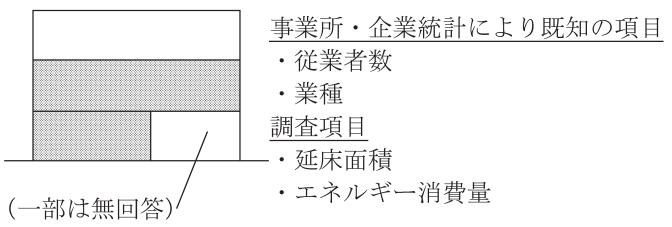

図 4 オーナー・テナントへの調査のイメージ

同一敷地内テナントが 50 超の場合の, 無作為抽出した 10 テナント. なお，それ以外の一般のビルについては，才 ーナーの名簿を補足していないため, 平成 17 年試験調査と同様にエネルギー消費把握状態に 関わらず無作為抽出を行い，ビルのオーナーで あればエネルギー消費把握状態により，回答す る項目が異なるように調査をした。

※省エネ法定期報告：省エネ法とは，「エネ ルギーの使用の合理化に関する法律」の通 称であり，一定量以上のエネルギー消費を 行っている工場・事業場に対して，エネル ギー消費量の報告を定期的に行うことを義 務付けている。平成 18 年度エネルギー消 費統計におけるビル等の調査の対象とする のは，定期報告の対象となっている工場・ 事業場のうち，業務部門のものとした。

これまでのヒアリング等により, オーナーと テナントは, 表 6 の範囲でエネルギー消費量を 把握していることを前提としている.
この結果を集計方法については，オーナー及 び共用部のエネルギーの消費量は，オーナーが 属する業種に，テナント部分については，テナ ントの属する業種の消費として集計した。

\section{5. 集計の方法}

エネルギー消費統計調査の集計は，原則，調 查の母集団設計に用いた，事業所・企業統計調 査の産業中分類 $\times$ 従業員規模 (8区分) マトリ クスごとに有効回答から算出した 1 事業所当た りのエネルギー消費量（エネルギー種類別）を 事業所数に乗ずることで算出した。

一事業所当たりの平均エネルギー消費量を算 出するにあたり，異常值除去の手法として箱ひ げの手法を採用した。箱ひげの除去対象となり ヒアリングにより正常と確認できた場合は，平 均值を算出には含めず，後で加える方法を採用 している。

また，産業中分類の中でエネルギー多消費型 
表 6 ビルのエネルギ一消費の把握状況

\begin{tabular}{|c|c|c|c|}
\hline & \multicolumn{2}{|c|}{ エネルギー消費 } & \multirow[t]{2}{*}{ 活動指標 } \\
\hline & ビル共用部分 & テナント部分 & \\
\hline $\begin{array}{l}\text { オ } \\
1 \\
+ \\
1 \\
1\end{array}$ & $\begin{array}{l}\text { ・把握している. エネルギー転換を } \\
\text { 行っている場合もある. }\end{array}$ & $\begin{array}{l}\text { ・テナント全体のエネルギー消費量 } \\
\text { は把握可能である場合が多い.た } \\
\text { だし, 内訳は不明である. } \\
\text { ・テナントが個別に契約を結んでい } \\
\text { るガス等のエネルギー消費量は把 } \\
\text { 握できない. }\end{array}$ & $\begin{array}{l}\text { •延床面積は把握している. } \\
\text { ・テナントの従業者数, 業種構成等 } \\
\text { は把握していない. }\end{array}$ \\
\hline $\begin{array}{l}\text { テ } \\
\text { ナ } \\
\text { ン } \\
\text { ト }\end{array}$ & $\begin{array}{l}\text { ・オーナー（もしくはオーナーから } \\
\text { 依頼された管理会社）から請求さ } \\
\text { れるエネルギー使用額に, 一部含 } \\
\text { まれる場合がある. }\end{array}$ & $\begin{array}{l}\text { •オーナー（もしくはオーナーから } \\
\text { 依頼された管理会社）から請求さ } \\
\text { れるエネルギー使用額を把握して } \\
\text { いるが，必ずしもテナント自身の } \\
\text { エネルギー消費量を反映している } \\
\text { わけではない. } \\
\text { •個別にガス供給契約を結んでいる } \\
\text { 場合や，灯油等を消費している場 } \\
\text { 合がある. }\end{array}$ & $\begin{array}{l}\text { • 延床面積, 従業者数を把握してい } \\
\text { る. }\end{array}$ \\
\hline
\end{tabular}

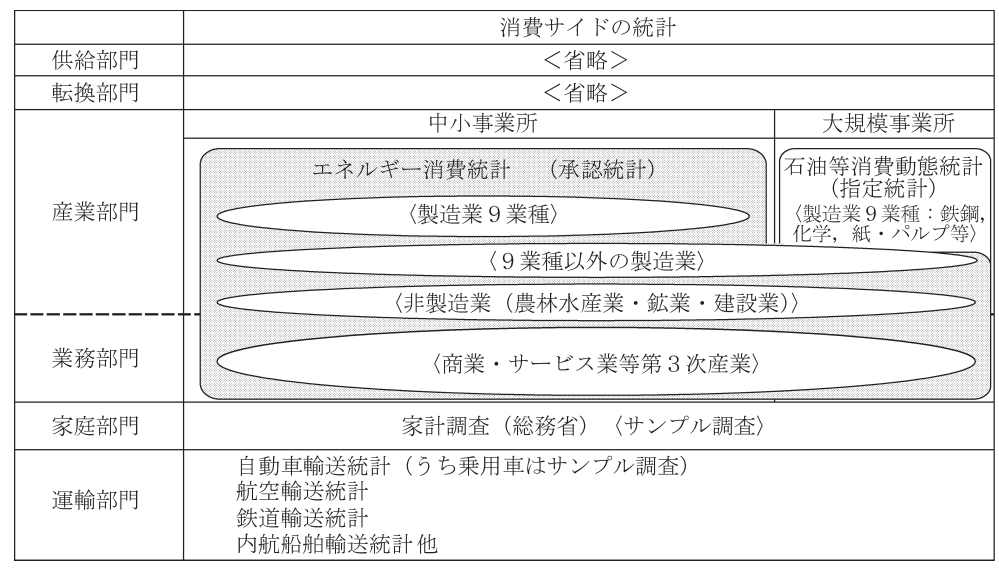

図 5 平成 19 年度エネルギー消費統計調査の把握範囲

とそうではない分類が含まれている場合は，小 分類まで細分化して平均を求め合算している. 繊維工業のうち染色整理業とそれ以外, 倉庫業 のうち冷凍倉庫業とそれ以外などが該当する。

平成 18 年度予備調査において第 4 号で調査 し, 有効回答を得た分は, 自ら使用部と共用部 はその回答した産業の消費に加え, テナント部 の消費については, 回答した敷地に属する事業 所の産業ごとの従業者数 $\times$ 一人当たりエネルギ 一消費量で按分し, 元の産業に加えて算出して いる.

さらに, 当初からエネルギー消費統計調査の 対象外とした，石油等消費動態統計調査を事業 所・企業統計調査の名簿と名寄せを行い, 該当
する産業分類に加えることで，エネルギー消費 統計調査の集計結果とした。

なお，ここでの従業者数は，事業所・企業統 計調査の従業者数に派遣入れを加え派遣出しを 差し引いた事業従事者の概念を採用している。 現に従事している者がエネルギー消費量により 相関があるためである。

\section{6. おわりに}

エネルギー消費統計調査を実施するにあたっ ての最大の懸案事項は, 既存の統計調査には, 事業所, 企業, 世帯と言った調査客体が確立し ているが，エネルギー消費についての調査客体 
は，事業所でも企業でも当てはまらない建物単 位が多いため, 調査客体の把握のための名簿の 整備が重要である。

平成 16 年, 平成 17 年の 2 回の試験調査と平 成 18 年度の予備調查をこれまで実施してきた が，今回の平成 19 年度調査においても前述の 問題が解決したわけでなく，今後も引き続き調 査の改善, 名簿の整備等短期的には解決しえな い課題を抱えており，調査が確立したとは言え ないので，引き続き試行錯誤が継続している. 現在実査を終了したばかりであるが，今後公表 する調查結果の利用については十分な留意が必 要である。

エネルギー消費統計調査は, 図 5 にあるとお り，既存の統計調査や行政資料において補足し ていない業種を調査しているので，調査の集計 結果が日本の全てのエネルギー消費量を説明し ているのではないことを留意して欲しい.

日本全体のエネルギー消費の実態は，「総合 エネルギー統計」にゆだねることになる。

また，全業種従業員規模別に 1 事業所あたり のエネルギー消費量を確保しているが，都道府 県等の地域別の集計については，全国集計につ いては，全都道府県の各業種ごとに有効回答が あるわけではないので, 近隣の地域の 1 事業所 あたりの值を代用して集計しているため，結果 には不安定な要素を包含しているので利用にあ たっては十分留意が必要となっている。

\section{〔注〕}

1）省エネ法定期報告事業所約 13,000 のうち，事業 所名称から, ビル, ショッピングセンター, 空港 と判断された約 2,000 事業所.

2）なお，同じ敷地（住所）に複数の省エネ法対象 事業場がある場合も，合わせて 1 つの「ビル」と して扱っている。

\section{参考文献}

高橋陸春（1981）「商鉱工業エネルギー消費統計につい て」経済統計研究財団法人通産統計協会

資源エネルギー庁編（2006）「総合エネルギー統計 (平成 16 年度版)」
参考

総合エネルギー統計は，昭和 28 年度（1953 年度）以 来, 各種の一次統計を基に作成されてきた。当初は, 日本国内で必要なエネルギーを供給することが政策の 主眼であったが，昭和 48 年（1973 年）及び昭和 54 55 年（1979 80 年）にかけての第一次，第二次石 油危機の厳しいエネルギー情勢下で, 我が国が中長期 的に安定した成長を確保し，国民生活の向上を図って いくために，石油の安定的供給及び石油代替エネルギ 一開発等の供給側の努力とともに, 省エネルギー及び 代替エネルギーの導入を推進する等の需要側の対応が 必要となった。しかしながら，当時は，供給サイドの データ（輸入統計，生産統計，需給統計）は相当程度 整備されていたが，需要サイドのデータは工業統計調 査や通商産業省生産動態統計調査（一部業種）など一 部の調査によって消費金額又は消費数量が把握されて いるに過ぎず，体系的なエネルギー消費統計としては 殆ど整備されていなかった。そこで，通商産業省では 昭和 55 年度（1980 年度）から，新たに「商鉱工業工ネ ルギー消費統計調査」を実施することとした。昭和 63 年度（1988 年度）版からは，石油等消費動態統計の対 象となっている一部の製造業では石油等消費動態統計 を，それ以外の部門について「エネルギー生産・需給 統計」の販売データ, 電力調査統計月報, ガス事業統 計等を用いて「総合エネルギー統計（新エネバラ）」を 作成するようになった。

商慣行の変化や 1990 年代後半以降の石油, 電力, ガ ス業界の規制緩和による新規参入者の増加等により， 2000 年頃には，供給側からのエネルギー消費量データ の精度やカバー率に疑念がもたれるようになってきた。 さらには, 作成基礎としていた各種統計の統廃合や, 部門区分の老朽化に伴う近年のエネルギー需給実態か らの乘離, 京都議定書の履行に際するエネルギー起源 $\mathrm{CO}_{2}$ 排出量の報告義務への対応の必要性，それに伴う国 内省エネルギー，省 $\mathrm{CO}_{2}$ 政策対応等といった状況の変 化があり，資源エネルギー庁では，平成 16 年度（2004 年度) 版から，石油等消費動態統計の対象となってい る一部の製造業では石油等消費動態統計を，それ以外 の部門については産業連関表から推計して「総合エネ ルギー統計（新・新エネバラ）」を作成することとし た.しかしながら, 産業連関表から推計する方法は, (1)エネルギー分野の自由化に伴い，金額から物量への 換算に使う単価が多様化したこと，(2) 5 年に一度作成 される産業連関表を外挿して最新年度の数値を推計す るために最大 9 年遅れで数值が確定值に変更される可 能性があること, 等の問題点が指摘されるようになっ た. 